\title{
The Constraints of Agricultural Credit and Government Policy Strategy
}

\author{
Sri Herliana*, Acip Sutardi, Qorri Aina, Qonita Himmatul Aliya, Nur Lawiyah \\ Institut Teknologi Bandung, School of Business and Management, Bandung, Indonesia
}

\begin{abstract}
Low access to credit in the agricultural sector is also caused by problems of agricultural sector actors (especially farmers) and financial institutions. Farmers are still having difficulty in accessing credit (accessibility and unbankable) and the limited financial institutions that channel credit to the agricultural sector. Therefore, the government must issue a policy in growing the agricultural sector, especially in anticipation of access credit constraints by farmers. The agricultural sector as a high-risk business, therefore formal institutions are less interested in financing the agricultural sector on the grounds of high transaction costs, asymmetric information, low profits, lack of collateral, education of farmers is relatively low. In addition, most banks do not want to finance agriculture due to fluctuating production and uncontrolled price risk. While the constraints of the farmers in obtaining formal credit is a complex procedure, there should be collateral as well as high payment delay fees, long distances and less information about capital.
\end{abstract}

\section{Introduction}

Agricultural Sector (viewed from production), based on data from the Central Bureau of Statistics [1](BPS, 2017 ) is the second most influential sector of economic growth, after processing industry. For the second quarter of 2017, the agricultural sector in a broad sense accounted for 13.92 percent, while in the first quarter of 2017 it contributed 13.59 percent. Compared to the previous quarter ( $\mathrm{q}$ to $\mathrm{q}$ ), the agricultural sector became the highest growth sector, at 8.44 percent. This increase is obtained from the increased production of a number of plantation crops such as coffee and sugar cane and from horticulture. Based on data from Indonesian Banking Statistics as of January 2017, credit distribution to agriculture, hunting and forestry sector amounted to Rp278 trillion $(6.45 \%)$ while credit to the fishery sector was only Rp9.14 trillion $(0.21 \%)$. The NPLs in both sectors reached Rp6.04 trillion (2.17\%) and Rp384 billion (4.21\%), respectively. Total bank credit until January 2017 reached Rp4,313 trillion. The credit distribution to the agricultural sector from the Bank is still small compared to other sectors. This is because credit risk to the agricultural sector has a high risk among others because it is directly related to nature. So that the banks remain cautious in holding public funds, and keep the credit given does not become a credit problem (non-performing loan / NPL). Low access to credit in the agricultural sector is also caused by problems of agricultural sector actors (especially farmers) and financial institutions. Farmers are still having difficulty in accessing credit (accessibility and unbankable) and the limited financial institutions that channel credit to the agricultural sector. Therefore, the government must issue a policy in growing the agricultural sector, especially in anticipation of access credit constraints by farmers.

\section{Literature Review}

\subsection{The Constraints of Agricultural Credit}

Agricultural credit constraints according to Minh Chau Tran et al (2016) there are some problems or constraints in access to agricultural credit. Agricultural credit problems will be related to the condition of a region or country. Credit as an important source to improve the welfare and production of farm households. But in the process, it is almost the same as incidence in many other developing countries, in rural Vietnamese agricultural households accessing credit to formal financial institutions is exempt due to high transaction costs and information asymmetries, lack of guarantees, weak credit contract enforcement and underdevelopment of insurance services make formal financial managers unable to serve the market this [2]. Another problem in accessing credit is the different treatment in the ease of obtaining credit. The distinguishing factors are the characteristics of head of household (age, sex and education), household characteristics (factors related to physical capital, factors related to human capital, social capital related factors and factors related to the economy), factors geographical factors (distance to markets or formal

\footnotetext{
* Corresponding author: sri.herliana@sbm-itb.ac.id
} 
lenders increase the transaction costs of households, the livelihood of local credit institutions and the development of local production.

Pavel Ciaian et al (2012) examines the impact of credit constraints on agricultural behavior in CEE transition countries. Based on the theoretical model shows that with the existence of binding credit limits, increased access to credit can lead to increased productivity, agricultural output and input use. With symmetric credit constraints, the eradication of agricultural credit constraints increases the use of all inputs [3]. However, if asymmetrically limited, increased access to credit may result in restricted credit input substitution to provide unlimited input. The results of empirical testing on the hypothesis show that the farm in CEE is restricted credit. Access to credit increases TFP up to 1.9 per cent EUR 1,000 of additional credit. Agriculture in CEE is primarily limited by credits involving variable inputs and capital investments, as variable inputs and capital investments increase respectively to 2.3 and 29 per cent per 1,000 EUR of additional credit. On the other hand, land and labor are not limited to credit. This could be due to the relatively high abundance of land and the high employment of agricultural labor in the CEE transition countries, especially in Poland, Slovenia and the Baltic countries. So the results showed that agriculture can address the problem of land financing and workforce with better than the input and investment variables. Family farms mainly use their own labor in production, which reduces the need for pre-financing. Family labor can overcome credit problems by delaying household consumption until the last period, when revenues from production sales are collected (after harvest at the end of the season). Similar to land. Agriculture can increase land use through the rental market.

The problems that occur in some developing countries in agricultural credit policy are similar to those in Indonesia. Based on Farida Siregar et al (2015) shows the result that the KUR Program was launched by the government to realize inclusive financing, especially for micro businesses to fund working capital and investment from formal bank loans. Of 332 respondents from household micro enterprises, $46.7 \%$ of respondents had access to KUR and the rest did not use KUR to fund their businesses. The results of this study indicate a determinant factor that significantly affects the access of household micro enterprises to KUR. Gender plays an important role in accessing KUR in household micro enterprises, including men, have a higher chance of accessing KUR than women. Property and property ownership in the name of the husband reduces the role of wife in getting a loan. Women have no interaction with formal institutions and sign loan contracts because they have little experience or low level of education. The longer business tenure and accessibility to alternative funding sources are factors that adversely affect their accessibility to KUR. The main reason is that capital needs are met without the need for KUR access from banks. Another case if the barriers faced by households due to limitations of micro-marketing, economies of scale low, so KUR is not the right solution [4].

With the constraints in accessing credit, it will certainly affect the production activities and welfare levels of farmers. Mamudu Abunga Akudugu (2016) examined the relationship between agricultural productivity and credit in a paper entitled "Agricultural productivity, credit and farm size in Ghana: a case study of Ghana. Overall, the results show that formal and informal credits have a positive and significant effect on agricultural productivity. The impact of formal credit on agricultural productivity is lower than that of informal credit. Although the size of the land is found not to be a linearly significant determinant of agricultural productivity of farm households, the quadratic term is. The implication of the results of this study is that efforts to promote agricultural productivity in Africa in general and Ghana in particular should focus on finding the right size of agricultural land for farmers taking into account the context in which farmers operate to be able to produce so as to produce at optimal pareto. Therefore, in making policy interventions in increasing agricultural productivity in Africa and Ghana in particular should be in accordance with the size of land owned by farmers. This is to ensure that farmers operate within the appropriate range of farm sizes that will make them economically viable. In addition, pre-harvesting contracts that are used as a proxy for market access have an insignificant effect on agricultural productivity. This suggests that interventions aimed at improving agricultural productivity should not focus on providing pre-harvest market contracts as this may lead to a decrease in productivity [5].

\subsection{Government Policy on Agricultural Credit}

The role of government in supporting the farmer's economy and overcoming the capital problem faced by farmers is by the inclusive financial system which among the programs is low interest credit and how to make the bankable farmers and get complete information about the capital. Some researchers have analyzed programs that have been done by the government. Here are presented research results in several countries as a comparative study.

Amruth Prasad Reddy and Venkata Subbaiah (2012) in his research results show that agricultural credit is a key factor to accelerate agricultural development in India. Farmers' credit needs are three kinds. First, farmers need short-term credit to finance agricultural operations such as purchasing seeds, pesticides and fertilizers. Secondly, they need mediumterm credit for the purchase of plows, farm equipment, tractors and other tools to cultivate their land with the help of modern tools Third, they need it for long-term agricultural development such as land improvement, border development and horticulture. To increase agricultural production, they have to borrow more credit. This paper examines the impact of agricultural credit on the working generation of farmers by age, 
education, caste, size, occupation in the delta and non delta regions of Nellore district of Andhra Pradesh [6].

Roy, Tuhin Narayan (2017) in his research, trying to quantitatively review the current scenario of access to agricultural credits by small and marginal farmers and their performance under the priority lending sector policy (PSL) in India from various secondary sources of information w.e.f. 2001 [7]. The objective of the PSL program is to ensure adequate credit for vulnerable economic sectors such as agriculture. Agricultural credit, in India, increased by 15.78 percent from FY10 to FY15. Despite various policy efforts to lend priorities to poor farmers, very little progress has been made. Nearly 51.9 percent of Indian farmers and 85 percent of marginal and small farmers are under debt but the formal credit provided to them is very poor $(30 \%)$. Only 40 percent of the total farmers have received Kishan Credit Card. Most PSL programs are linked to interest rates. As per the RBI policy, 40 percent of loans must go to the PSL sector where 18 percent will go to agriculture. But, that's only 13 percent by 2015. Due to changes in norms and regulations, PSL coverage already exists. The share of direct agricultural loans to marginal farmers has fallen sharply from almost 23 percent in 2005 to just 4.3 percent in 2013. They are 85.03 percent at no. ownership and 44.5 percent in the operated area. But, the stock is now only 7 percent and 8 percent respectively. Indian agricultural production and credit levels have shown a positive growth rate. But lending to farmers does not encourage an increase in agricultural credit but also the agribusiness sector and companies involved in agriculture. Thus, the delivery and access of agricultural credit to poor farmers under PSL has not been satisfactory. Experts emphasize the government's proactive role and advise that the design and innovation of PSL policies be implemented effectively. Therefore, it is suggested that more efforts can be undertaken such as alternative livelihoods, poverty alleviation, mainstreaming of marginalized groups and promotion of appropriate technologies / inputs for production, income and quality of life of small and marginal farmers.

Joseph Chisasa and Daniel Makina (2015) shows that there is a positive and significant relationship between bank credit, capital formation and agricultural output in South Africa [8]. The empirical results of this study indicate that, in the short term, capital formation has a positive and significant effect on agricultural output. So while credit may have a negative impact on agricultural yields in the short term, long-term adjustment mechanisms which have a rapid positive impact. Based on the Engle-Granger causality test conducted, it is concluded that there is a positive relationship of (1) bank credit to the growth of agricultural output; (2) agricultural products on capital formation; (3) agricultural products for labor; (4) capital formation into credit; (5) the formation of capital for labor, and bi-directional causality between credit and labor.
Swamy, Vighneswara (2010), in the results of his research show that equal growth is important for inclusive growth which in turn can lead to sustainable growth. Access to finance by the poor is a prerequisite for reducing poverty and sustainable economic development. This study has determined that there is a strong need to strengthen the policy approach to finance the priority sector in India because it has a positive impact on inclusive growth. Given the strong relationship between priority sector lending and inclusive growth, it is imperative for policymakers in general and governments in particular to make efforts to encourage banks and financial institutions to increase lending to priority sectors beyond the prescribed conditions. Priority sector lending in India has been heavily influenced by the lending approach of Government policy in India. Priority sector loans over the period of the year in Indian banks have had a positive impact on inclusive growth. Given the strong relationship between priority and inclusive sector lending, it is imperative for policymakers in general and the government in particular to make an effort to motivate banks and financial institutions in increasing priority sector lending beyond the provisions laid down by the Reserve Bank of India banks in India and expanding their businesses exponentially to reach priority sectors in providing fair and equitable financial aid to achieve inclusive growth [9].

\section{Results and Discussion}

\subsection{The Constraints of Agricultural Credit}

Based on a review of several papers, farmers' problems in accessing agricultural credit in detail are as follows:

1. Difficulty Fulfilling the Requirements (Unbankable). To access credit from a financial institution or Bank, the common valuation criteria must be met by the customer using $5 \mathrm{C}$ analysis. Character is the nature or character of a person; Capacity is an analysis to know the ability of customers in paying credit; Capital is a state of wealth owned by a company managed by a prospective debtor; Condition is an analysis that considers the economic condition seen from prospective business prospects; Collateral is a guarantee provided by a prospective customer both physical and non-physical. However, in reality farmers are still constrained in meeting the requirements of the Bank (unbankable). Reinforced by the results of research Farida, et al (2014) showed that the agricultural sector is the lowest sector that get KUR. Agriculture is considered a high-risk sector, therefore formal institutions avoid financing the sector for the following reasons; high transaction costs, asymmetric information, low profits, lack of collateral, low education and low literacy.

2. Low Return Loan Guarantee. This is because agriculture is considered a high-risk sector, therefore formal institutions avoid financing the sector for the following reasons; high transaction 
costs, asymmetric information, low profits, lack of collateral, low education and low literacy. Generally, banks do not want to finance agriculture due to fluctuating production and uncontrolled price risk. It is like the result of Rahmatullah (2010) research that credit granting is still mostly handled by Central Government Bank, Regional Development Bank or small lending bank although the local bank is closer to the government and agricultural credit distribution is still small compared to the distribution to other sectors [10]. Meanwhile, according to Darmawanto (2008), the Bank in lending is always bound by the prevailing law, in the case of credit distribution to the agricultural sector there is a contradiction of interests, on the one hand the Government / Bank Indonesia seeks credit development in the agricultural sector, on the other hand emphasizes the prudential principle in each disbursement with the risk of any credit degradation without special treatment [10].

3. Credit Market Failure. The bargaining position of farmers at this time is generally weak, this is one obstacle in an effort to increase the income of farmers. The weak bargaining position of farmers is due largely to the market structure at the farm level is monopolistic. In this structure, some traders / wholesalers who control market access, market information, and capital adequately deal with many farmers who lack market access, market information and capital are inadequate, so to access credit even farmers are in a position of lack of information and weak in fulfilling the requirements. So the subsidy or low interest credit given by the government is not so much accessible to farmers. In this structure it is assumed that the trader has full power over the commodity sold by the farmer, but the trader is in the pure competitive market structure of the transaction with the aggregate agricultural commodity market (the trader can not affect the aggregate market of agro-commodities, but only the transactions at the farm level). In addition to facilitate the analysis, it is assumed there is no marketing and processing costs so that the price at the trader equal to the price in the market of producer centers. Not all household loan applications in rural areas are approved by the banks although they are willing to pay higher interest rates (incomplete market). With the incomplete market, farmers borrow their capital at informal financial institutions even with high interest rates. This is supported by Minh Chau Tran's (2016) study that informal credit plays an active role in increasing household income that is constrained by credit when it is a sufficient supplement to formal credit. this per capita consumption variable shows that creditconstrained households receiving sufficient credits from informal sources can improve their per capita consumption.

4. Differences Treatment in Accessing Credit. Farida's research, et al (2014) shows that there are several factors that can significantly affect the access of people's business credit programs. This includes gender, length of business, business barriers, bank accounts, spousal working and other sources of lending. Based on the results of the odds ratio, it was concluded that men were 6.56 times more likely to have access to credit than women. People who have bank accounts have a 3.66 times greater chance of getting credit. New ventures facing capital constraints and those whose partners work tend to access KUR. Gender plays an important role in accessing KUR in household micro enterprises, including men, have a higher chance of accessing KUR than women. Property and property ownership in the name of the husband reduces the role of wife in getting a loan. Women have no interaction with formal institutions and sign loan contracts because they have little experience or low level of education. While Minh Chau Tran's research (2016) shows that young and under-educated households with female heads are under-financed from formal financial institutions. Similarly, the size of agricultural land, labor resources and nonagricultural income play an important role in reducing the status of household credit constraints.

\subsection{Government Policy Strategy}

With the problems faced by farmers in accessing and managing agricultural credits (formal), the agricultural credit policy instruments are prepared, as follows: (1) Launched low-interest agricultural credit, and (2) Implementing an inclusive financial system.

\subsubsection{Low-interest agricultural credit}

In facing the problems of farmers in the aspect of funding for the sustainability of farming and meet the needs of households, agricultural credits with low interest is needed. But farmers and small businesses often face obstacles in fulfilling credit access requirements and lack of information. Therefore, the government provides assistance by legalizing credit programs for MSMEs in the form of People's Business Credit (KUR). The program was launched to support government programs in efforts to alleviate poverty and reduce unemployment. The program was adopted on 5 November 2007 by President Susilo Bambang Yudhoyono. Businesses financed by KUR include trade, agriculture, communications, restaurants, and others. The KUR program was born in response to Presidential Instruction No. 6 Year 2007 on the Policy of Acceleration of Real Sector Development and Empowerment of Micro, Small and Medium Enterprises. The Presidential Instruction was followed up with the signing of a Memorandum of 
Understanding (MoU) between the Government, Guarantee Institution and Banking on October 9, 2007 as amended by addendum on 14 May 2008 on Credit Guarantee / Financing to MSMEs and Cooperatives or more popular with the term of the People's Business Credit Program (KUR). The objective of the KUR program is to accelerate the development of economic activities in the real sector in the context of poverty alleviation and expansion as well as the expansion of employment opportunities. Result of Limited Cabinet Meeting dated June 17, 2015 which decides that the KUR interest rate for debtors is a maximum of $12 \%$ effective per annum. At Permenko 6/2015 the sector funded by KUR only covers the agriculture, fisheries, processing industries, and trade sectors related to the three sectors. The expansion of sector in Permenko $8 / 2015$ is the trade sector is not restricted anymore but covers all business in trade sector and some service sector. As the legal basis for the determination of interest rates charged to debtors from $12 \%$ to $9 \%$ in 2016, issued Permenko 13 of 2015 on December 30, 2015. The interest rate reduction is intended to further encourage micro, small and medium enterprises. In the implementation or implementation of KUR, there are three important pillars: the government that functions to assist and support the implementation of credit provision along with credit guarantee, Guarantee Institution which acts as the guarantor of credit / financing channeled by Banking and Banking as recipient of guarantee functioned to distribute credit to UMKM and cooperatives using their own internal funds. Referring to the KUR legal foundation above, the KUR program scheme is different from either the empowerment / assistance program to the community or with other program credit schemes that have been issued by the government. KUR is a Working Capital Credit or Investment Credit financed entirely from banking funds, provided to MSME and new Cooperative with maximum credit limit of Rp. 500 million / debtors [12].

Subsequent developments in order to support financing for Micro, Small and Medium Enterprises (MSMEs), the Government through the Coordinating Minister for Economic Affairs decided to lower the KUR interest rate in 2018 from the original $9 \%$ effective per year to $7 \%$. Effective interest per year. The new KUR interest will be effective starting January 1, 2018. Coordination meeting attended by Minister of Industry Airlangga Hartarto, Head of BPKP Ardan Adiperdana and related ministry / agency representatives also decided to increase the target of KUR distribution in the production sector (agriculture, fisheries, processing industry, construction and production services) in 2018 to a minimum of $50 \%$ of the total distribution target of Rp 120 trillion. This is because MSMEs in the production sector (agriculture, fishery, processing industry, construction and production services) are difficult to get credit / financing from Financial Institutions, since the production sector has a relatively higher risk than the trade sector. In order to encourage the acceleration of
KUR distribution in the production sector, the Policy Committee has also prepared a new KUR scheme, specifically KUR for the smallholder plantation sector, and community farming. Special KUR is a KUR scheme given to a group of businesses that are managed jointly in cluster form by using business partners for community plantation commodities, and community farms. The Special KUR ceiling is set at $\mathrm{Rp} 25$ million -Rp 500 million for each individual member of the group. In the future, the Policy Committee will set the KUR ceiling for 2018 for each KUR Distributor, taking into account the recommendations of the Financial Services Authority (OJK).

The role of government in supporting the farmer's economy and overcoming the capital problem faced by farmers is by the inclusive financial system which among the programs is low interest credit and how to make the bankable farmers and get complete information about the capital. Some researchers have analyzed programs that have been done by the government. Here are presented research results in several countries as a comparative study.

\subsubsection{Inclusive Finance}

Inclusive finance is one of the solutions to overcome farmers' barriers to accessing formal financial systems. The Government launched the National Strategy for Inclusive Finance and the National Council for Inclusive Finance with the issuance of Presidential Decree No. 82 of 2016 on the National Strategy for Inclusive Finance. The objective of which is for the public to gain access to wider financial institutions so that they can improve their business activities such as in agriculture, livestock or fisheries. With this inclusive financial system, farmers who have unbankable become bankable and receive financial management assistance.

Inclusive Finance (financial inclusion) is an entire effort that aims to eliminate all forms of barriers that are price and non-price, to access the community in utilizing financial services. This inclusive finance is a national strategy to encourage economic growth through equal distribution of income, poverty alleviation and financial system stability.

In the National Strategy for Inclusive Finance, the inclusive financial strategy is outlined in six pillars: financial education, public finance facilities, financial information mapping, supporting policies / regulations, intermediation and distribution facilities, and consumer protection. Some examples of inclusive financial implications in helping farmers other than KUR are as follows:

1. Digitalization of payment of Business to Person (B2P) and Government to Person (G2P). The financial gap in rural areas is still very large, where most of the small farmers are still untouched by the services and products of banks. Without having a bank account, many small farmers are running their economy in cash, both in receiving payments for 
the sale of crops and in receiving social assistance from the government. The digitization of Business to Person (B2P) and Government to Person (G2P) payments in agriculture is evolving into a new opportunity for electronic money service providers to help drive rural growth, in line with their efforts to expand services outside of urban areas and into segments the new one. Digital payments to electronic wallets belonging to smallholders will reduce the time and cost of cash transactions because they no longer require a long journey just to receive and pay in cash. In addition, this has also resulted in increased security and transparency. The digitization of payments will be an entry point for inclusive finance for farmers who have not been touched by banks, where the use of electronic money in agricultural payments will create a financial identity for them and be able to open the door to wider financial services such as savings and loans.

2. Information Systems for Farmers \& Fishermen (SIPN). In the agricultural sector there is a need for up-to-date and inaccessible information. The existence of asymmetric information has resulted in bargaining position of farmers and fishermen becoming weak. Therefore, in order to overcome this problem, it is necessary to provide information system for farmers and fishermen, ie input material price such as fertilizer price, seeds, pest medicines, supporting information, such as weather and farming / distribution, and product selling price. Information Systems for Farmers and Fishermen (SIPN) or Mobile Agriculture should be simple, user friendly and at an affordable cost. One model of information dissemination is through mobile phones. This is considering the high number of mobile phone users in Indonesia [13].

\section{Conclusion}

Credit constraints on the agricultural sector as a highrisk business, therefore formal institutions are less interested in financing the agricultural sector on the grounds of high transaction costs, asymmetric information, low profits, lack of collateral, education of farmers is relatively low. In addition, most banks do not want to finance agriculture due to fluctuating production and uncontrolled price risk. While the constraints of the farmers in obtaining formal credit is a complex procedure, there should be collateral as well as high payment delay fees, long distances and less information about capital.

Government policy on agricultural credit is the strategy of inclusive Finance is a national development strategy to encourage economic growth through equal distribution of income, poverty alleviation and financial system stability. This community-centered strategy needs to target groups experiencing barriers to accessing financial services. The inclusive financial strategy explicitly targets the groups with the greatest or unfulfilled needs for financial services ie the three categories of people (the poor, low-income, working poor / poor and the near-poor) and three crosscategories (migrant workers, women and the population underdeveloped regions). To realize a sustainable inclusive financial program, coordination between Bank Indonesia and the relevant ministries and institutions is required in the framework of developing, prioritizing and implementing the program, and monitoring and evaluating the program. With good coordination is expected to increase the goal of community access to financial services can be achieved. One of the inclusive financial programs needed to address farmers 'problems in terms of funding for sustainability of their farming and to meet their household needs is low-interest agricultural credit is needed such as KUR and farmers' development from unbankable to bankable.

\section{References}

1. Central Bureau of Statistics (BPS). https://www.bps.go.id/

2. Minh Chau Tran,Cristopher Gan, Baiding $\mathrm{Hu}$. Credit Constraints and Their Impact on Farm Household Welfare: Evidence from Vietnam's North Central Coast Region. International Journal of Social Economics, 782-803, (2016)

3. Pavel Ciaian, Jan Falkowski d'Artis Kancs, Access to credit, factor allocation and farm productivity: Evidence from the CEE transition economies. Agricultural Finance Review Vol. 72 No. 1, (2012)

4. Farida, F., Siregar, H., Nuryartono, N., \& Intan, E. K. Micro Enterprises' Access to People Business Credit Program in Indonesia: Credit Rationed or Non-Credit Rationed? International Journal of Economic Perspectives, 9(2), 57-70, (2015)

5. Mamudu Abunga Akudugu. Agricultural productivity, credit and farm size nexus in Africa: a case study of Ghana. Agricultural Finance Review Vol. 76 No. 2, 2016 pp. 288-308, (2016)

6. Amruth Prasad Reddy, Venkata Subbaiah. Impact of Agricultural Credit on Employment Generation of The Farmers. Journal of Commerce \& Accounting Research Volume 1 Issue 1 January (2012)

7. Roy, Tuhin Narayan. Study on Access to Farm Credit by the Small and Marginal Farmers in India under the Policy on Priority Sector Lending (PSL) Economic Affairs; New Delhi Vol. 62(1), 39-45. (2017)

8. Joseph Chisasa. Bank Credit and Agricultural Output in South Africa: Cointegration, Short Run Dynamics and Causality. The Journal of Applied Business Research -31(2), (2015)

9. Swamy, Vighneswar. Financial Development and Inclusive Growth: Impact of Government Intervention in Prioritised Credit. Zagreb International Review of Economics \& Business;13(2) 55-72, (2010) 
10. Rahmatullah Rizieq. Analisa Dampak Kredit Pertanian pada Pertumbuhan Sektor Pertanian dan Ekonomi. Jurnal Visis Ekonomi, 9 (2), (2010).

11. Darmawanto. Pengembangan Kredit Sektor Pertanian. Program Magister Ilmu Hukum Program Pasca Sarjana Universitas Diponegoro, Semarang, (2008)

12. http://www.bi.go.id/id/perbankan/keuanganinklus if/program/sipn/Contents/Default.aspx

13. http://keuanganinklusif.co.id/artikel/81pembayaran-di-bidang-pertanian-berbasisdigitalisasi 